\title{
DETOXIFICATION FUNCTION OF GEOPHAGY AND DOMESTICATION OF THE POTATO
}

\author{
TIMOTHY JOHNS \\ Division of Biological Sciences and Museum of Anthropology \\ University of Michigan \\ Ann Arbor, Michigan 48109
}

(Received April 30, 1985; accepted July 8, 1985)

\begin{abstract}
Detoxification as the adaptive function of geophagy is demonstrated from field and historical data associating clay consumption with the domestication of potentially toxic potatoes. In vitro analyses showed that the glycoalkaloid, tomatine, was effectively adsorbed by four classes of edible clays over a range of simulated gastrointestinal conditions. These results, in conjunction with reports of geophagy by nonhuman primates, suggest geophagy as a solution to the impasse chemical deterrents pose to the process of domestication and to chemical constraints on plant exploitation by non-fireusing hominids. The inorganic component of the chemical environment deserves increased attention from chemical ecologists.
\end{abstract}

Key Words-Geophagy, hominid, primate, detoxification, glycoalkaloids, tomatine, domestication, potatoes, clay-organic interactions.

\section{INTRODUCTION}

Selection for changes in secondary chemical constituents has been an essential aspect of the domestication of food plants (Rindos, 1980). However, it is problematic as to how the wild progenitors of staple cultigens with appreciable levels of toxins would have been acceptable initially for human consumption, and therefore subject to genetic manipulation. Cooking has been suggested as the major technological mechanism for making plant foods available to humans (Stahl, 1984; Leopold and Ardrey, 1972). However, heat-stable toxins would remain serious deterrents to foragers, including those with controlled fire. The heat-stable, water-insoluble glycoalkaloids of the potato, which are considered

${ }^{1}$ Current address: Department of Entomological Sciences, University of California, Berkeley, California 94720. 
in the present study, are not destroyed by cooking. I present evidence associated with the domestication of the potato to show that geophagy was crucial to this process.

I suggest that geophagy is the most basic human detoxification technique with behavioral antecedents that are prehominoid. Soil consumption has been observed in many animals, including invertebrates (Shachak et al., 1976) and reptiles, birds, and mammals (Marlow and Tollestrup, 1982; Smith 1979). Although clays may (or may not) be important nutritionally, they may at least have a detoxification function in mammals. Geophagy in rats has been interpreted to have evolved in relation to the gastrointestinal illness that occurs after eating toxic substances (Mitchell et al., 1976; Burchfield et al., 1977).

The role of geophagy in the detoxification of alkaloids, tannins, and quinones is suggested by several cases of geophagy recorded in the anthropological literature (Laufer, 1930; Anell and Lagercrantz, 1958). In nonhuman primates, the nature of geophagy has led primate ecologists to suggest that a detoxification function in relation to plant secondary compounds is being served (Hladik, 1977).

Interpretation of the adaptive significance of geophagy associated with potato consumption and domestication is decidedly less problematic than with other cases where geophagy and organic toxins have been linked, in that detoxification is the explicit intent of those who practice it. Indians of the American Southwest and adjacent Mexico consume clays with the wild potato species, $S$. jamesii Torr. and S. fendleri Gray (Laufer, 1930; Whiting, 1939). The expressed reason for the consumption of specific clays is their effectiveness in eliminating bitterness and in preventing stomach pains or vomiting that result from eating large quantities of these foods without clay. Similar reports of Andean native consumption of specific clays with potatoes date from the 16thcentury chroniclers (Weiss, 1953). Specific clays are still consumed with frostresistant potato cultigens (Solanum $\times$ juzepczukii Buk. and $S . \times$ curtilobum Juz. et Buk.) by the inhabitants of the Central Andean altiplano, with the stated rationale of eliminating the bitter taste characteristic of these potatoes.

Clays are obtained from locally well-known sites in both North and South America. In Peru and Bolivia, I have seen excavations for edible clays extending two or three meters below the surface. Edible clays may be used medicinally, but they are distinguished from clays used for other purposes such as pottery making and for whitewash. Remnants of the historical trade in edible clays persist among the Quechua and Aymara of southern Peru and Bolivia (Rowe, 1946; Tschopik, 1946). Andeans distinguish quality of edible clays largely on the basis of texture. Of the two Peruvian clays, ch'aqo and p'asalla (Table 1), the former is judged superior because of the relative ease with which it breaks up in water. Andeans consume unseasoned potatoes as the sole or dominant constituent of a meal. Bitter potatoes are dipped in a thick slurry of 
Table 1. Origin of Field-Collected Clays

\begin{tabular}{|c|c|}
\hline Clay (language) & $\begin{array}{l}\text { Geographical origin and collection } \\
\text { data }\end{array}$ \\
\hline P'asa (Aymara) & $\begin{array}{l}\text { Achocalla, Prov. Murillo, Dept. } \\
\text { La Paz, Bolivia; June 22, 1983; } \\
\text { purchased in Villa Remedios, } \\
\text { Prov. Ingavi. }\end{array}$ \\
\hline $\begin{array}{l}\text { P'asalla (Aymara, } \\
\text { Quechua) }\end{array}$ & $\begin{array}{l}\text { Tincopalca, Prov. San Roman, } \\
\text { Dept. Puno, Peru; July 14, } \\
\text { 1981; purchased in Mercado } \\
\text { Mancocapa, Juliaca, Prov. } \\
\text { Puno. }\end{array}$ \\
\hline $\begin{array}{l}\text { Ch'aqo (Aymara, } \\
\text { Quechua) }\end{array}$ & $\begin{array}{l}\text { Acora, Prov. Puno, Dept. Puno, } \\
\text { Peru; July 15, 1981; purchased } \\
\text { in Puno, Prov. Puno. }\end{array}$ \\
\hline Dleesh (Navajo) & $\begin{array}{l}\text { Chinlee area, Navajo Reservation, } \\
\text { Arizona, U.S.A.; July 1, 1981; } \\
\text { collected by Wendy Wolfe. }\end{array}$ \\
\hline
\end{tabular}

clay. Indians of the American Southwest consumed potatoes both cooked and raw. Clays were reportedly added during cooking (Bailey, 1940) or were taken with each mouthful of potato (Whiting, 1939).

Solanine, the bitter glycoalkaloid common in most potatoes, is considered to be toxic to humans in quantities above $20 \mathrm{mg} / 100 \mathrm{~g}$ fresh weight (Gregory, 1984; Jadhav et al., 1981), although cases of solanine poisoning are rare. Glycoalkaloid poisoning involves gastrointestinal and neurological disturbances similar to those caused by the related classes of steroid glycosides, saponins and cardiac glycosides (Jadhav et al., 1981). Tuber-bearing species of Solanum vary in the identity and quantity of the glycoalkaloids contained (Gregory et al., 1981; Osman et al., 1978; Johns, 1985). The pharmacokinetics of clayorganic interactions have been studièd under gastrointestinal conditions (White and Hem, 1983), and adsorption is generally either through ion-exchange and/ or physical adsorption (Theng, 1974). Naturally occurring alkaloids have been shown to be effectively bound by clays (Hendricks, 1941; Wai and Banker, 1966; Ridout, 1967; Barr and Arnista, 1957). The degree of binding depends on reaction conditions (White and Hem, 1983) and on the nature of the clays (Barr and Arnista, 1957; McGinity and Hill, 1975).

In this study the detoxification potential of geophagy was estimated by measuring the adsorptive capacity for tomatine of four potato clays that were recognized as distinct by native practitioners. Qualitative mineral composition was determined with $\mathrm{X}$-ray diffraction. 
Materials. All of the four clays used with potatoes (see Table 1 for sources) were obtained as dry solid pieces. In preparation for adsorption assays, clays obtained from the field were pulverized in a mortar. Field samples and standards were elutriated with 15 times their weight of deionized water for $1 \mathrm{~h}$. Samples were decanted to remove large particles of clay and sand. The decanted portion was centrifuged at $15,000 \mathrm{~g}$ for $10 \mathrm{~min}$, and the pellet was dried at $80^{\circ} \mathrm{C}$, repulverized, and stored in a desiccator until used. Kaolin and bentonite were purchased from Sigma Chemical Co.

$X$-Ray Diffraction. Clays were characterized by powder pattern X-ray diffraction. Air-dried and glycolated preparations were analyzed by M. Cosca, Department of Geology, University of Michigan.

Determination of Adsorptive Capacity. Adsorption of alkaloids on wellcharacterized clays such as kaolin has been shown to follow an isotherm represented by the Langmuir equation (Barr and Arnista, 1957; Ridout, 1967). The adsorption of a representative and commercially available glycoalkaloid, tomatine, by four sample clays, ch'aqo, p'asalla, p'asa, and dleesh, and by commercially available clays, kaolin and bentonite, was determined using the linear form of the Langmuir adsorption isotherm:

$$
\frac{C}{X / M}=\frac{1}{a b}+\frac{1}{b} C
$$

where $C$ is the equilibrium concentration of tomatine in solution, and $X / M$ is the amount of tomatine adsorbed per gram of adsorbant. Constants are designated as $a$ and $b$, with $b$ being equal to the monolayer capacity of the adsorbant.

Adsorptive capacity was determined by stirring 6-mg samples of clay with tomatine (concentration $2-10 \mathrm{mg} / 10 \mathrm{ml}$ ) in $10 \mathrm{ml}$ of buffer (ammonium acetate, $\mathrm{pH} 5.5$ ) at room temperature for $1 \mathrm{hr}$. Equilibrium concentrations $(C)$ of tomatine were determined. All tubes were centrifuged for $10 \mathrm{~min}$ at $14,500 \mathrm{~g}$, and a 5-ml aliquot of the supernatant was freeze-dried. The aglycone, tomatidine, was obtained by hydrolyzing samples in $10 \mathrm{ml}$ of $2 \mathrm{~N} \mathrm{H}_{2} \mathrm{SO}_{4}$ heated at $100^{\circ} \mathrm{C}$ for $2 \mathrm{hr}$. Aglycones were precipitated with concentrated $\mathrm{NH}_{4} \mathrm{OH}$ and were extracted with benzene. Known amounts of tomatine in four concentrations were taken through the lyophylization, hydrolysis, and extraction procedures in each experiment, and served as standards. The quantity of tomatidine present was determined using a titration method (Fitzpatrick and Osman, 1974). The inverse of the slope $(1 / b)$ of a linear regression of $C /(X / M)$ on $C$ for each clay sample was used to determine the adsorptive capacity $(b)$.

Adsorptive Capacity under Physiological Conditions of $\mathrm{pH}$ and Ionic Strength. The effect of $\mathrm{pH}$ on tomatine adsorption was determined for $p^{\prime}$ asa and bentonite using the method described above. Solutions were buffered over 
a pH range of $\mathrm{pH} 5.5-1.5$, using $0.1 \mathrm{M}$ ammonium acetate (pH 5.5 and 4.5) and $0.1 \mathrm{M}$ ammonium formate ( $\mathrm{pH} 3.5$ and 1.5). Adsorptive capacities under stomach conditions were simulated at $\mathrm{pH} 2.0$ and $0.075 \mathrm{M}$ for $p$ 'asa, bentonite, and dleesh.

Determination of the adsorptive capacity at reduced ionic strength was not possible at $\mathrm{pH} 5.5$ or above because of the limited solubility of tomatine (cf. $\mathrm{pK}_{\mathrm{a}}$ of $\alpha$-solanine $=6.6$ (Windholz, 1976)). The effect of ionic strength on the adsorption of tomatine was determined at $\mathrm{pH} 4.5$ for $p$ 'asa and bentonite using concentrations of ammonium acetate varying from 0.15 to $0.01 \mathrm{M}$. Adsorption under unbuffered conditions was determined for p'asa and bentonite using a starting $\mathrm{pH}$ of 2.5. Determinations at $\mathrm{pH} 5.5$ and ionic strength of 0.15 were used to approximate sorption in the intestinal tract for p'asa, bentonite, and dleesh.

\section{RESULTS AND DISCUSSION}

Adsorptive Capacities of Potato Clays. Qualitative characterizations of the four field-collected clays are recorded in Table 2. The sample of $p$ 'asa showed high interlayer swelling in water. Many of its properties were similar to those of bentonite.

Values of the adsorptive capacities for tomatine for each of the clay samples at $\mathrm{pH} 5.5$ and $0.1 \mathrm{M}$ ammonium acetate are shown in Table 2. These determinations are representative of binding under oral conditions. Significant differences $(P<0.05)$ in slopes are seen between all clays tested (analysis of covariance). Assays with kaolin showed experimental variation that was difficult to correct with the experimental methods used. The steep slope of the Langmuir isotherm for kaolin as compared to those of montmorillonite clays such as bentonite and p'asa is consistent with the weak cation-exchange capacity of kaolin (Barr and Arnista, 1957; Meshali, 1982).

The adsorption of tomatine by the six clay samples and standards follows a pattern consistent with the known cation-exchange capacities and intercalation properties of different clay groups (Theng, 1974). With an adsorptive capacity of $0.50 \mathrm{~g} / \mathrm{g}$ ( $\mathrm{pH} 5.5,0.1 \mathrm{M}$ ammonium acetate), the Bolivian clay, $p$ 'asa, is superior to bentonite (adsorptive capacity: $0.37 \mathrm{~g} / \mathrm{g}$ ), one of the best commercially available adsorbants of organic compounds. At $\mathrm{pH} 4.5$ and $0.01 \mathrm{M}$ buffer concentration, p'asa and bentonite have capacities of 0.68 and $0.65 \mathrm{~g} / \mathrm{g}$, respectively. For unbuffered samples, adsorptive capacities of $0.61 \mathrm{~g} / \mathrm{g}$ and 0.64 $\mathrm{g} / \mathrm{g}$, respectively, were recorded for the two clays. Under these conditions of low ionic strength, tomatine adsorption by bentonite is comparable on a milligram basis to that of previously studied pharmaceutical agents (Wai and Banker, 1966).

Of the four clay samples, the weakest adsorption was shown by dleesh, 
Table 2. Characterization of Clays and Comparison of Detoxification Potentials as Represented by Adsorptive Capacities for TOMatine

\begin{tabular}{|c|c|c|}
\hline Clay & Characterization & $\begin{array}{c}\text { Adsorptive capacity } \\
{\left[\mathrm{g} / \mathrm{g}\left(r^{2}\right)\right]}\end{array}$ \\
\hline P'asa & $\begin{array}{l}\text { Predominantly } \\
\text { smectites, mixed- } \\
\text { layered with illite; } \\
\text { quartz. High interlayer } \\
\text { swelling. }\end{array}$ & $0.50(0.99)$ \\
\hline P'asalla & $\begin{array}{l}\text { Mixed-layer of } \\
\text { smectites and illite; } \\
\text { quartz. }\end{array}$ & $0.28(0.94)$ \\
\hline Ch'aqo & $\begin{array}{l}\text { Predominantly illite, } \\
\text { mixed-layered with } \\
\text { smectites, chlorite, } \\
\text { kaolinite; quartz. }\end{array}$ & $0.19(0.98)$ \\
\hline Dleesh & $\begin{array}{l}\text { Predominantly illite, } \\
\text { mixed-layered with } \\
\text { smectites, kaolinite, } \\
\text { chlorite; quartz }\end{array}$ & $0.14(0.97)$ \\
\hline Bentonite & & $0.37(0.98)$ \\
\hline Kaolin & & $0.05(0.77)$ \\
\hline
\end{tabular}

obtained from the Navajo reservation. Its adsorptive capacity of $0.14 \mathrm{~g} / \mathrm{g}$ is, nonetheless, approximately three times greater than Kaolin under similar conditions.

Effects of pH and Ionic Strength on Adsorptive Capacity. The adsorptive capacities of tomatine by $p$ 'asa and bentonite show no significant $(P>0.05)$ differences between $\mathrm{pH} 5.5$ and 1.5 (Table 3 ). The lack of appreciable effects due to increasing proton concentration is consistent with other studies that have considered the adsorption of organic bases onto clays (Meshali, 1982; Browne et al., 1980). The $\mathrm{pK}_{\mathrm{a}} \mathrm{s}$ of the alkaloid portion of glycoalkaloids favor the protonated form under experimental conditions.

The increased binding of tomatine as ammonium acetate concentration is decreased from 0.15 to $0.01 \mathrm{M}$ is highly significant $(P<0.0001)$ for both $p$ 'asa and bentonite (Table 4). The nature of the competition for negatively charged sites between tomatine and other cations will depend on the exchangeable cations present on the surface of the clays and the particular cations present in solution (McGinity and Hill, 1975).

Sorption of high-molecular-weight cations has been shown to involve both ion-exchange and physical adsorption and to reach adsorption levels that exceed the cation-exchange capacity of the clays (Wai and Banker, 1966). At low ionic strength, $0.66 \mathrm{meq} / \mathrm{g}$ of tomatine were adsorbed per gram of $p$ 'as $a$, while ben- 
Table 3. Effect of pH on Adsorptive Capacity of P'asa and Bentonite

\begin{tabular}{lcccc}
\hline & & \multicolumn{3}{c}{ Adsorptive Capacity $\left[\mathrm{g} / \mathrm{g}\left(r^{2}\right)\right]$} \\
\cline { 3 - 5 } $\mathrm{pH}$ & Ionic & P'asa & Bentonite & Dleesh \\
\hline 5.5 & 0.10 & $0.50(0.99)$ & $0.37(0.98)$ & \\
4.5 & 0.10 & $0.45(0.98)$ & $0.41(0.96)$ & \\
3.5 & 0.10 & $0.50(0.97)$ & $0.42(0.97)$ & \\
2.5 & 0.10 & $0.50(0.99)$ & $0.46(0.98)$ & \\
1.5 & 0.10 & $0.48(0.99)$ & $0.44(0.98)$ & $0.11(0.93)$ \\
2.0 & 0.075 & $0.49(0.97)$ & $0.43(1.00)$ & \\
\hline
\end{tabular}

Table 4. Effect of Ionic Strength on Adsorptive Capacity of P'asa and Bentonite

\begin{tabular}{lcccc}
\hline & & \multicolumn{3}{c}{ Adsorptive Capacity $\left[\mathrm{g} / \mathrm{g}\left(r^{2}\right)\right]$} \\
\cline { 3 - 5 } $\begin{array}{c}\text { Ionic } \\
\text { strength }(\mathrm{M})\end{array}$ & $\mathrm{pH}$ & P'asa & Bentonite & Dleesh \\
\hline 0.15 & 5.5 & $0.40(0.99)$ & $0.30(0.98)$ & $0.03(0.98)$ \\
0.15 & 4.5 & $0.45(0.97)$ & $0.33(0.99)$ & \\
0.10 & 4.5 & $0.45(0.98)$ & $0.41(0.96)$ & \\
0.05 & 4.5 & $0.58(0.99)$ & $0.46(1.00)$ & \\
0.01 & 4.5 & $0.68(0.99)$ & $0.65(0.99)$ & \\
Unbuffered & 2.5 & $0.61(0.99)$ & $0.64(0.99)$ & \\
& (initial) & & & \\
\hline
\end{tabular}

tonite adsorbed $0.63 \mathrm{meq} / \mathrm{g}$. On a molar basis, the measured values of tomatine are, in fact, less than the average meq/g reported for montmorillonite clays $(0.8-1.5 \mathrm{meq} / \mathrm{g})$. The failure of tomatine to occupy all sites available for cation exchange most likely represents a "cover-up effect" (Hendricks, 1941). The large size of the tomatine molecule (mol wt 1034) exceeds the area available per exchange site.

Detoxification under Physiological Conditions. Adsorption studies over the range of conditions encompassing gastrointestinal $\mathrm{pH}$ and ionic strength (Lentner, 1981) demonstrate the ability of these edible clays to bind tomatine and hence neutralize the bitterness and eliminate the gastrointestinal irritation associated with glycoalkaloid ingestion (Jadhav et al., 1981). The quantities of clay necessary to reduce glycoalkaloids from a level of $100 \mathrm{mg} / 100 \mathrm{~g}$ fresh weight, typical of wild potatoes (Gregory, 1984), to a recognized nontoxic level of $20 \mathrm{mg} / 100 \mathrm{~g}$ (Gregory, 1984) are minuscule in comparison to the amounts that are consumed at an actual meal (Whiting, 1939). Culinary practices of 
Andeans and the Hopi, as described above, should facilitate glycoalkaloid adsorption.

The determinations of adsorptive capacity made at $\mathrm{pH} 5.5$ and $0.1 \mathrm{M}$ ammonium acetate account for the decrease in bitterness reported by native peoples. Soluble molecules of glycoalkaloids available to interact with oral receptors are also those available for clay adsorption.

The overall detoxification of the clays is most dependent on adsorption in the stomach. Determinations of adsorptive capacity at $\mathrm{pH} 2.0$ and $0.0075 \mathrm{M}$ monovalent cation concentration (ammonium ion) reflect binding during the gastric residence period. Under these conditions, only $271 \mathrm{mg}$ of the least adsorbant of the clays, dleesh, would reduce a toxic level of $50 \mathrm{mg}$ tomatine in $100 \mathrm{~g}$ of potatoes to the recognized nontoxic level of $20 \mathrm{mg} / 100 \mathrm{~g}$ TGA. P'asa, the most effective adsorbant would provide the same detoxification with only $60 \mathrm{mg}$ of clay.

Desorption at the increased $\mathrm{pH}$ and ionic strength of the intestines could reduce the effective detoxification of clays. At $\mathrm{pH} 5.5$ and $0.15 \mathrm{M}$ ammonium acetate, the adsorptive capacities of $p^{\prime}$ 'asa, bentonite, and dleesh are the lowest in comparison to all the conditions tested. The reduced solubility of glycoalkaloids at pHs above 5.5 would be expected to reduce adsorption under normal intestinal pHs of 6-8 (Lentner, 1981). Previous work (White and Hem, 1983) has shown that in vivo, in the presence of clays, $\mathrm{pK}_{\mathrm{a}} \mathrm{s}$ are effectively higher. Such an effect would facilitate clay-tomatine binding in vivo. Even if clay adsorption of glycoalkaloids is reduced in the intestine, their insolubility under basic conditions should minimize adsorption by the intestine and decrease the resultant toxic effects.

Evolutionary Significance of Geophagy by Humans. Wild potatoes, as weedy annuals occurring in abundance on sites of human disturbance, meet the classic criteria for a domesticable plant (de Wet and Harlan, 1975). However, weakly toxic glycoalkaloids, while not eliminating the possibility of consumption, would limit the use of potato tubers to a casual occurrence or as an emergency food. Geophagous practices associated with the gathering of potatoes from the wild (Laufer, 1930), and with the cultivation of wild potatoes (Whiting, 1939; cf. Pennington, 1963) and primitive domesticates (Weiss, 1953) link this detoxification phenomenon with the process of human-directed evolution leading to plant domestication. Association of the detoxification function of geophagy with stages in the domestication of the world's premier vegetatively propagated cultigen (FAO, 1983) has important implications, as well, for the domestication of many crops where wild relatives contain toxic levels of secondary compounds.

The clay-potato association provides insight into the general phenomenon of geophagy. Potato clays are used habitually with a resource which otherwise is only modestly exploitable because of the presence of weak but quantitative 
toxins. The use of clays in this situation corresponds to geophagous practices of at least eight species of primates which include at least some leaves in their diet (Hladik, 1978; Wrangham, personal communication). Nonlethal quantities of secondary compounds limit the exploitation of particular abundant resources by generalist herbivores (Freeland and Janzen, 1974) and constrain primate food choice (Clutton-Brock, 1977; McKey et al., 1981). Specific clays, often from termite mounds, are eaten daily, sometimes seasonally, by chimpanzees (Uehara, 1982; Wrangham, 1977; Hladik and Gueguen, 1974).

If early human foraging was analogous to the feeding of modern nonhuman primates, then food procurement by humans must have been subject to the constraints imposed by plant defensive compounds. Geophagy is a behavior with antecedents that are certainly prehominoid, and higher primates, including humans, have apparently maintained it as a mechanism for dealing with naturally occurring toxins.

Rats consume clay when subjected to chemical toxins in laboratory settings (Mitchell et al., 1976, 1977a). Mitchell et al. (1977b) demonstrated that if a rat develops a conditioned taste aversion to a novel (and nontoxic) flavor, it will respond to this conditioned stimulus by consuming clay, even if clay was not administered during the original conditioning episode.

The conditioned aversion response has been extensively studied in rats and other animals (Garcia et al., 1974; Riley and Baril, 1976) and has provided a model for considering human taste aversions and preferences (Garb and Stunkard, 1974; Garcia et al., 1974; Bernstein, 1978). The well-studied model linking toxicosis and conditioned responses, mediated through gastrointestinal upset, can be extended to include geophagy as part of an integrated "psychological" response to environmental toxins. This model may be extended to include geophagy as an adaptive behavioral response for generalist primates as well as rats.

Widespread medicinal uses of clays by humans to treat diarrhea (Vermeer and Ferrell, 1985) and other gastrointestinal ailments may relate to the detoxification function of geophagy either directly or indirectly via the "psychological" response to gastrointestinal upset.

Periodic deficiencies in food availability are a fundamental stress facing humans and other primates (Stahl, 1984). Wild potatoes are typically exploited by humans during famines or periods of seasonal scarcity (Laufer, 1930; Whiting, 1939). Geophagy accompanying the use of famine foods is a widely documented behavior of traditional agriculturalists around the world (Laufer, 1930; Solien, 1954). Here geophagy is a response to gastrointestinal stress in the form of hunger (Solien, 1954) or poisoning by ingestion of barely tolerable wild plants or bacterially contaminated foods. The most appropriate responses to this stress are maintained and transmitted through human culture and institutions. Modern cultural attitudes towards geophagy are clearly important in encour- 
aging or restricting this behavior. Maintenance of geophagy as a cultural trait may be a relic of its historical significance (Laufer, 1930; Anell and Lagercrantz, 1958; Hunter, 1973).

Crises in food production are an inherent component of many models of the development of agriculture (Rindos, 1980). The transition of geophagy from a general response to toxin-related stress to a more specialized detoxification technique can be interpreted as an important step allowing expanded resource exploitation and the domestication of particular plants. Wild potatoes were presumably a minor dietary constituent or a famine resource under primitive conditions of exploitation, but eventually provided a subsistence base for complex prehistoric civilization in the Central Andes. By analogy, wild plants were probably more available to early hominids than has been previously supposed (Leopold and Ardrey, 1972).

The functional significance of geophagy suggests that the interaction of animals with the inorganic component of the chemical environment deserves increased attention from chemical ecologists. Animals ingest exogenous substances for nutritional, digestive (Martin and Martin, 1978), defensive, and communicative purposes (Harborne, 1982). Clearly they ingest exogenous substances for their detoxification properties as well.

Acknowledgments--This paper is dedicated to the late Prof. Volney H. Jones. I thank M.M. Martin, S.F. Osman, H.V. Kuhnlein, M. Cosca, W.L. Merrill, and C.I.P. (Lima) for technical support; W. Wolfe for the sample of dleesh; and A. Camino, R.I. Ford, R.W. Wrangham, and S.L. Keen for their comments. This research was supported by a NSERC Canada Postgraduate Scholarship and a NSF Dissertation Grant (DEB-8208298).

\section{REFERENCES}

ANELl, B., and LaGercrantz, S. 1958. Geophagical customs. Stud. Ethnogr. Ups. 17:1-84.

Barley, F.L. 1940. Navaho foods and cooking methods. Am. Anthropol. 42:270-290.

BARR, M., and ARNISTA, E.S. 1957. Adsorption studies on clays 1: The adsorption of two alkaloids by attapulgite, halloysite and kaolin. J. Am. Pharm. Assoc. 46:486-489.

BERNSTEIN, I.L. 1978. Learned taste aversions in children receiving chemotherapy. Science 200:1302-1303.

Browne, J.E., Feldkamp, J.R., White, J.L., and Hem, S.L. 1980. Acid-base equilibria of tetracycline in sodium montmorillonite. J. Pharm. Sci. 69:811-815.

BurChField, S.R., Elich, M.S., and Woods, S.C. 1977. Geophagia in response to stress and arthritis. Physiol. Behav. 19:265-267.

ClutTon-Brock, T.H. (ed.) 1977. Primate Ecology: Studies of Feeding and Ranging Behavior in Lemurs, Monkeys, and Apes. Academic Press, London, $631 \mathrm{pp}$.

DE WET, J.M.J., and HARLAN, J.R. 1975. Weeds and domesticates: Evolution in the man-made habitat. Econ. Bot. 36:225-241.

FAO. 1983. FAO Production Yearbook, Vol. 37. Food and Agriculture Organization of the United Nations, Rome. 320 pp.

FItzPATRICK, T.J., and OsMAN, S.F. 1974. A comprehensive method for determination of total potato glycoalkaloids. Am. Potato J. 51:318-323. 
FREELAND, W.J., and JANZEN, D.H. 1970. Strategies in herbivory by mammals: The role of plant secondary compounds. Am. Nat. 108:269-289.

Garb, J.L., and Stunkard, A.J. 1974. Taste aversions in man. Am. J. Psychiatry. 131:12041207.

Garcia, J., Hankins, W.G., and RusiniaK, K.W. 1974. Behavioral regulation of the milieu interne in man and rat. Science 185:824-831.

GreGORY, P. 1984. Glycoalkaloid composition of potatoes: Diversity and biological implications. Am. Potato J. 61:115-122.

Gregory, P., Sinden, S.L., Osman, S.F., Tingey, W.M., and Chessin, D.A. 1981. Glycoalkaloids of wild, tuber-bearing Solanum species. J. Agric. Food Chem. 29:1212-1215.

HARBORNE, J.B. 1982. Introduction to Ecological Biochemistry, 2nd ed., Academic Press, London, $278 \mathrm{pp}$.

HENDRICKS, S.B. 1941. Base exchange of the clay mineral montmorillonite for organic cations and its dependence upon adsorption due to van der Waals forces. J. Phys. Chem. 45:65-81.

HLADIK, C.M. 1977. Chimpanzees of Gabon and Gombe: Some comparative data on the diet, pp. 481-501, in T.H. Clutton-Brock (ed.). Primate Ecology. Academic Press, London.

HLADIK, C.M. 1978. Adaptive strategies of primates in relation to leaf-eating, pp. 373-395, in C.G. Montgomery (ed.). The Ecology of Arboreal Folivores. Smithsonian Institution Press, Washington, D.C.

HladiK, C.M., and Gueguen, L. 1974. Geophagie et nutrition minerale chez les primates sauvages. C.R. Acad. Sci., Paris 279:1393-1396.

HUNTER, J.M., 1973. Geophagy in Africa and in the United States: A culture-nutrition hypothesis. Geogr. Rev. 63:170-195.

JadHaV, S.J., Sharma, R.P., and Salunkhe, D.K. 1981. Naturally occurring toxic alkaloids in foods. C.R.C. Crit. Rev. Toxicol. 9:21-104.

JoHns, T.A. 1985. Chemical Ecology of the Aymara of Western Bolivia: Selection for Glycoalkaloids in the Solanum $X$ ajanhuiri Domestication Complex. PhD dissertation. University of Michigan, Ann Arbor, $312 \mathrm{pp.}$

Laufer, B. 1930. Geophagy. Field Mus. Nat. Hist., Anthropol. Ser. 18:99-198.

Lentner, C. (ed.) 1981. Geigy Scientific Tables. Vol. 1. Medical Education Division Ciba-Geigy Corporation, West Caldwell, New Jersey, $97 \mathrm{pp}$.

Leopold, A.C., and ARDrey, R. 1972. Toxic substances in plants and the food habits of early man. Science 176:512-514.

Marlow, R.W., and Tollestrup, K. 1982. Mining and exploitation of natural mineral deposits by the desert tortoise, Gopherus agassizii. Anim. Behav. 30:475-478.

Martin, M.M., and MarTin, J.S. 1978. Cellulose digestion in the midgut of the fungus-growing termite Macrotermes natalensis: The role of acquired digestive enzymes. Science 199:14531455.

MCGiNTY, J.W., and HiLL, J.A. 1975. Influence of monovalent and divalent electrolytes on sorption of neomycin sulfate to attapulgate and montmorillonite clays. J. Pharm. Sci. 64:15661568.

McKey, D.B., Cartlan, J.S., Waterman, P.G., and Choo, G.M. 1981. Food selection by black colobus monkeys (Colobus satanas) in relation to plant chemistry. Biol. J. Linn. Soc. 16:115146.

MESHALI, M.M. 1982. Adsorption of phenazopyridine hydrochloride on pharmaceutical adjuvants. Pharmazie 37:718-720.

Mrtchell, D., Welis, C., Hoch, N., Lind, K., Woods, S.C., and MitChell, L.K. 1976. Poison induced pica in rats. Physiol. Behav. 17:691-697.

Mitchell, D., BEATTY, E.T., and Cox, P.K. 1977a. Behavioral differences between two populations of wild rats: Implications for domestication research. Behav. Biol. 19:206-216.

Mitchell, D., Winter, W., and MorisaKi, C.M. 1977b. Conditioned taste aversions accom- 
panied by geophagia: Evidence for the occurrence of "psychological" factors in the etiology of pica. Psychosomat. Med. 39:402-412.

OSman, S.F., Herb, S.F., FitzPatrick, T.J., and Schmiediche, P. 1978. Glycoalkaloid composition of wild and cultivated tuber-bearing Solanum species of potential value in potato breeding programs. J. Agric. Food Chem. 26:1246-1248.

Pennington, C.W. 1963. The Tarahumar of Mexico: Their Environment and Material Culture. University of Utah Press, Salt Lake City, 267 pp.

RIDOuT, C.W. 1967. The adsorption of atropine from aqueous solution by kaolin. Pharm. Acta Helv. 13:42-49.

Riley, A.L., and BARIL, L.L. 1976. Conditioned taste aversions: A bibliography. Anim. Learn. Behav. 4:1s-13s.

Rindos, D. 1980. Symbiosis, instability, and the origins and spread of agriculture: A new model. Curr. Anthropol. 21:751-772.

Rowe, J.H. 1946. Inca culture at the time of the Spanish conquest, pp. 183-330, in J.H. Steward (ed.). Handbook of South American Indians, Vol. 2. Bureau of American Ethnology, Bulletin 143, Smithsonian Institution, Washington, D.C.

Shachak, E.A., Chapman, Y., and Steinberger, Y. 1976. Feeding, energy flow and soil turnover in the desert isopod, Hemilepistus reaumuri. Oecologia 24:57-69.

Sмітн, M. 1979. Behavior of the koala, Phascolarctos cinereus Goldfuss, in captivity I. Nonsocial behavior. Aust. Wildl. Res. 6:117-129.

SoLIEN, N.L. 1954. A cultural explanation of geophagy. Fla. Anthropol. 7:1-9.

StAHL, A.B., 1984. Hominid dietary selection before fire. Curr. Anthropol. 25:151-168.

ThEnG, B.K.C. 1974. The Chemistry of Clay-Organic Reactions. John Wiley \& Sons, New York. $343 \mathrm{pp}$.

TSCHOPIK, H. 1946. The Aymara, pp. 501-573, in J.H. Steward (ed.). Handbook of South American Indians, Vol. 2. Bureau of American Ethnology, Bulletin 143, Smithsonian Institution, Washington, D.C.

UeHARA, S. 1982. Seasonal changes in the techniques employed by wild chimpanzees in the Mahale Mountains, Tanzania, to feed on termites (Pseudacanthotermes spiniger). Folia Primatol. 37:44-76.

Vermeer, D.E., and Ferrell, R.G. 1985. Nigerian geophagical clay: A traditional antidiarrheal pharmaceutical. Science 227:634-636.

WAI, K.-N., and BANKER, G.S. 1966. Some physiochemical properties of the montmorillonites. $J$. Pharm. Sci. 55:1215-1220.

WeIss, P. 1953. Los comedores peruanos de tierras. Peru Indigena 5:12-21.

WHITE, J.L., and HeM, S.L. 1983. Pharmaceutical aspects of clay-organic interactions. Ind. Eng. Chem. Prod. Res. Dev. 22:665-671.

Whiting, A.F. 1939. Ethnobotany of the Hopi. Mus. North. Ariz. Bull. 15:1-120.

Windholz, M. (ed.). 1976. The Merck Index. Merck \& Co., Rahway, New Jersey, 1313 pp.

WranghaM, R. 1977. Feeding behavior of chimpanzees in Gombe National Park, pp. 504-538, in T.H. Clutton-Brock (ed.). Primate Ecology. Academic Press. London. 